\title{
Foucault’s Discourse and Power: Implications for Instructionist Classroom Management
}

\author{
Victor Pitsoe, Moeketsi Letseka \\ Department of Educational Leadership and Management, \\ College of Education, University of South Africa, Pretoria, South Africa \\ Email: Pitsovj@unisa.ac.za
}

Received October 23 ${ }^{\text {rd }}$, 2012; revised November 27 ${ }^{\text {th }}$, 2012; accepted December $8^{\text {th }}, 2012$

\begin{abstract}
This article picks up on Foucault's radical reconceptualisation of concept "power", and presents a significant challenge to contemporary discourses surrounding instructionist classroom management. We critique his approach to instructionist classroom management on the basis that it conceptualises power as domination in dealing with disruption in the classroom. We argue that power and discourse are interrelated constructs that the teacher uses to perpetuate Taylorism, Fordism and bureaucratic domination in an instructionist classroom setting. Drawing on Foucault's and Bourdieu's works, this document reviews: 1) explores Foucault's theory of discourse; 2) argues discourse as an instrument of power; 3) captures the philosophical perspectives on instructionist classroom management; and 4) argues a teacher's power as a tool for social reproduction and domination in instructionist classroom setting.
\end{abstract}

Keywords: Discourse; Power; Instructionist Classroom Management; Bureaucratisation; Taylorism; Fordism; Social Reproduction

\section{Introduction}

Michel Foucault's work is not alien to the field of educational management. As noted by Deacon (2006: p. 177), his detailed studies of madness, punishment, sexuality, and the human sciences have provided educational theorists with a whole new array of concepts (like discipline, and problematisation, analytical techniques (such as archaeology, and genealogy) and arguments (as pertaining to the intimate embrace of knowledge and power, and ways in which human subjects relate ethically to themselves and others). Foucault's work also offers nuanced understandings of the manifestations, functioning and effects of contemporary educational institutions and practices, more specifically in classroom management. Classroom management is a collection of theoretical ideas, teaching strategies and techniques utilised for the maintenance of classroom (school) order or "institutional equilibrium".

With this in mind, in the field of education, particularly in teacher training, the idea of "classroom management" occupies a central place in educational institutions and among practitioners. Exceptionally, its persistence is indicated in the rise of research on classroom management, as teacher training shifts from what were once considered "control" practices to an emphasis on "management" practices. Another indication of classroom management's status is the number of classroom management workshops available in educational fields ranging from special education to in-service teacher training. For many teachers, the shift from "controlling" to "managing" represents a progressive and unambiguous improvement.

This article picks up on Foucault's radical reconceptualisation of the concept "power", and presents a significant challenge to contemporary discourses surrounding educational management practices, especially with regard to instructionist classroom management. Power is not something that is ac- quired, seized or shared, something one holds on to or allows to slip away (Foucault, 1972: p. 94). In this article, we critique his approach to instructionist classroom management on the basis that it conceptualises power as domination in dealing with classroom disruption and discipline. We argue that power and discourse are interrelated constructs which the teacher uses to perpetuate Taylorism, Fordism and bureaucratic domination in an instructionist classroom setting. This article explores the poststructuralist theory of discourse, power and its implications on instructionist classroom management. It captures how poststructuralist theory can produce politically useful understandings of the production and reproduction. Drawing on Foucault's and Bourdieu's works, this article: 1) explores Foucault's theory of discourse; 2) argues discourse as an instrument of effecting power; 3) captures the philosophical perspectives on instructionist classroom management; and using Bourdieu's work; and 4) argues teachers' power as a tool for social reproduction and domination in an instructionist classroom setting. Lastly, some concluding remarks are offered.

\section{Foucault's Theory of Discourse}

Michel Foucault's discourse theory has been an important ground on which educational debates, policies, and scholarship have focused. Much of Foucault's thinking drew on elements in French anthropological thought from Durkheim and Mauss to Callois and Bataille about sacred collective representations as structural preconditions of cultural reproduction (Harrington 2006: p. 39). He continues to stand as an intellectual giant in the field of social and cultural inquiry-his works have farreaching influence. Interestingly, Foucault's theory of discourse occupies a place of comparative stability, especially when compared with the work of other (more controversial) post-modern icons such as Jacques Derrida's theories of “deconstruction” or 
Jean Baudrillard's contentions of "hyperreality". For example, Foucault's theory of discourse has been studied by other thinkers, such as Giorgio Agamben, Anthony Giddens, Judith Butler and Kai Alhanen who have combined Foucault's thought with that of Walter Benjamin and Carl Schmitt. Within social contexts, discourse theory is concerned with issues of power and domination. Hence, this article perceives Foucault's theory of discourse as both generative and illustrative of an intellectual tradition that provides certain breaks with the ordering principles of critical traditions dominating Western Left thinking since the turn of the century. Foucault's work illustrates a move within critical traditions to focus on knowledge as a material element in social life (Popkewitz, 1997: p. 288). Foucault's ideas, as noted by Harrison (1992: p. 84), offer both radical epistemological decenterings of knowledge and truth.

The concept "discourse" is multidimensional, broadly perceived and has several definitions. A plethora of literature notes that in the study of language, discourse often refers to the speech patterns and usage of language, dialects, and acceptable statements within a community. It is a subject of study about people who live in secluded areas and share similar speech conventions. Sociologists and philosophers tend to use the term "discourse" to describe the conversations and the meaning behind them by a group of people who hold certain ideas in common. The concept "discourse" originates from Latin "discursus", meaning "running to and from", and generally refers to "written or spoken communication". In the simplest sense, discourse is conversation or information. For Foucault (1977), it is through discourse (through knowledge) that we are created; and that discourse joins power and knowledge, and its power follows from our casual acceptance of the "reality with which we are presented".

Discourse, as a social construct, is created and perpetuated by those who have the power and means of communication. For example, those who are in control decide who we are by deciding what we discuss. Foucault holds that truth, morality, and meaning are created through discourse. In every society the production of discourse is at once controlled, selected, organised and redistributed according to a certain number of procedures, whose role is "to avert its powers and its dangers, to cope with chance events, to evade its ponderous, awesome materiality". Weedon (1997: p. 105) asserts that discourses, in Foucault's work, are ways of constituting knowledge, together with the social practices, forms of subjectivity and power relations. Discourse transmits and produces power; it undermines and exposes it, renders it fragile and makes it possible to thwart it (Weedon, 1997: p. 107). For Foucault (1972), discourses are about what can be said and thought, but also about who can speak, when, and with what authority. They embody meaning and social relationships, they constitute both subjectivity and power relations; and are "practices that systematically form the objects of which they speak. In addition, discourses are not about objects; they do not identify objects, they constitute them and in the practice of doing so conceal their own invention" (Foucault, 1972: p. 49).

Discourses exist both in written and oral forms and in the social practices of everyday life (Weedon, 1997: p. 108), and are inherent in the very physical layout of our institutions such as schools, churches, law courts and homes. As observed by Foucault, language plays a powerful role in reproducing and transforming power relations along many different dimensions (of class, culture, gender, sexuality, disability and age, etc.) and is sanctioned; the techniques and procedures accorded value in the acquisition of truth; the status of those who are charged with saying what counts as true. Hence, Foucault suggests that each society has its regime of truth, its "general politics" of truth: that is, the types of discourse it accepts and makes function as true; the mechanisms and instances which enable one to distinguish between true and false statements.

Discourses are constituted by exclusions as well as inclusions, by what cannot as well as what can be said. These exclusions and inclusions stand in antagonistic relationship to other discourses, other possible meanings, other claims, rights, and positions. This is Foucault's principle of discontinuity: "We must make allowance for the complex and unstable powers whereby discourse can be both an instrument and an effect of power, but also a hindrance, a stumbling block, a point of resistance and a starting point for an opposing strategy" (Foucault, 1978: p. 101). Power and knowledge are two sides of a single process. Knowledge does not reflect power relations but is imminent in them.

Poststructuralists see power as a form of hegemony. In hegemony, the oppressed class literally "gives" the oppressors the permission to oppress them. Much of the hegemony occurs through social practices and beliefs which neither the oppressors nor the oppressed are aware of, thus the necessity for raising the consciousness of people as a prerequisite for true freedom. Although Foucault sought to develop a new theory of society, he doubted through most of his career that this freedom could actually be achieved.

To sum up, discourse is interwoven with power and knowledge to constitute the oppression of those "others" in our society, serving to marginalise, silence and oppress them. They are oppressed not only by being denied access to certain knowledge, but by the demands of the dominant group within the society that the "other" shed their differences (in essence, their being, their voices, their cultures) to become "one of us". Control of knowledge is a form of oppression-only certain groups have access to certain knowledge. Those in positions of power are responsible for the assumptions that underlie the selection and organisation of knowledge in society. The task for the educator is to discover the patterns and distributions of power that influence the way in which a society selects, classifies, transmits, and evaluates the knowledge it considers to be public. Thus, discourse ultimately serves to control not just what but how subjects are constructed. Language, thought, and desire are regulated, policed, and managed through discourse.

\section{Discourse as an Instrument of Effecting Power}

Modern discourse about power began with Nicollò Machiavelli (The Prince, early 16th century) and Thomas Hobbes (Leviathan, mid-17th century). Their books are considered classics of political writing. With this in mind, Foucault's notion of discourse is a vital methodological concept in unraveling power in the poststructuralist era. It is in discourse that power and knowledge are joined together. As Hutcheon (1991) observes, discourse is not merely a tool of domination, rather, it is an instrument of power. In addition, it is both an instrument and an effect of power. According to a widely accepted view, power is a tool for the social construction of reality. According to this view, discourse is seen as an instrument of power and ideological control, but also as a hindrance, a stumbling block, a 
point of resistance and a starting point for an opposing strategy. Foucault (1978) asserts that discourse can transmit, produce, and reinforce power, but at the same time discourse can undermine and expose power, rendering it unstable and possible to thwart. Discursive practices are practices that a subject embodies, lives, and experiences as s/he interacts with discourses. For example, the discourse of femininity inadvertently informs, influences, and shapes women's identity to the point where women act out and behave according to what has been labelled as acceptable and true about females.

The concepts of discourse, power, culture and language are dialectically interrelated - they complement one another. Discourses, in turn, are shaped and informed by practices. Discourse and practices then enter into power relations. One does not have more or less power than the other but each equally shapes the other (Foucault, 1977). Discourse can be seen in the everyday practice of humans. Therefore, discourse is not only text but also action. Discourses are not once and for all subservient to power or raised up against it We must make allowances for the complex and unstable process whereby a discourse can be both an instrument and an effect of power, but also a hindrance, a stumbling point of resistance and a starting point for an opposing strategy. Discourse transmits and produces power; it reinforces it, but also undermines and exposes it, renders it fragile and makes it possible to thwart (Foucault, 1998: p. 100).

It is worth commenting on the aspect of language. Corson (1995) conceives language as an instrument of power and a useful tool for deconstructing power discourse. In a similar vein, Bourdieu (1977) notes that language is not only an instrument of communication or even knowledge, but also an instrument of power. For Ball and Goodson (2007: p. 176), at one level, power can readily be understood as coercive force or restraint. What is much more difficult to comprehend, is the idea of power being exercised through consent, through what Antonio Gramsci called "ideological hegemony". In most societies, the education system is controlled by the state, but it works to maintain relations of power throughout the society as a whole. Hence, the official discourses of the state relating to educational policies (e.g. core curriculum, transition education, systems of assessment or school management) are obvious instances in which discourse becomes the instrument and the object of power (Ball \& Goodson, 2007: p. 177).

Societal discourse mediates its power and control through institutions and elites "who are charged with saying what counts as true” (Talbani, 1996: p. 67). Each society, according to Foucault, has its regime of truth, its "general politics of truth, that is, the type of discourse it accepts and makes function as true". He sees society as an arena for a struggle to establish and pass on a regime of truth and develop techniques and procedures to inculcate and transmit cultural values considered to be true. Hence, a discourse could be an "instrument of power or an effect of power," as well as "a point of resistance and a starting point for an opposing strategy". Societal discourse mediates its power and control through institutions and elites "who are charged with saying what counts as true". A regime uses political, economic, and social apparatuses to control and dominate (Talbani, 1996). In addition, truth is established through the discourse of power that is relayed, pre-served, and legitimised. This involves a struggle around political debate and social confrontation—an ideological struggle (Talbani 1996).
Hence, the creation of educational or social institutions is part of the power struggle to establish, expand, and sustain a particular notion of truth through control over the power of legitimacy. Foucault (1972) notes that truth should be understood as a "system of ordered procedures for the production, regulation, distribution, circulation, and operation of statements".

As Foucault (1972) states, every educational system is a means of maintaining or modifying the appropriateness of discourses with the knowledge and power they bring with them. Education may well be, as of right, the instrument whereby every individual, in a society like our own, can gain access to any kind of discourse. However, we well know that in its distribution, in what it permits and in what it prevents, it follows the well-trodden battle lines of social conflict. Every education system is a political means of maintaining or of modifying the appropriation of discourse, with the knowledge and the powers it carries with it (Foucault, 1972).

Power is both a social and multi-layer construct. Also, it is a product of social relations and is culturally, socially and symbolically created. As Foucault (1978: pp. 42-43) puts it, power would no longer be dealing simply with legal subjects over whom the ultimate dominion was death, but with living social beings, and the mastery it would be able to exercise over them would have to be applied at the level of life itself; it was the taking care of life, more than the threat of death, that gave power its access, even to the body. The idea that the body is an important site for the exercise of power can be located within a Foucaultian framework in which the rise of capitalism can be seen to create a new domain of political life, referred to by Foucault as "bio-power" (Kehily, 2001). Here, power is conceptualised as decentralised and productive of social relations in common-place encounters and exchanges. From this perspective, the politics of the body plays an important part in disciplining individual bodies and regulating collective bodies such as populations or specific social groups (Kehily, 2001). For Foucault, the body is discursively constructed, realised in the play of power relations, and specifically targeted in the domain of the sexual. Foucault, in his work History of Sexuality, saw sex as a political issue, crucial to the emergence and deployment of bio-power: It [sex] was at the pivot of the two axes along which developed the entire political technology of life. On the one hand, it was tied to the disciplines of the body: the harnessing, intensification and distribution of forces, the adjustment and economy of energies. On the other hand, it was applied to the regulation of populations, through all the farreaching effects of its activity.

Against this backdrop, Foucault's thoughts offer a fairly structuralist account of the effects of discourse, knowledge, and power on society. Foucault's work is, thus, neither truly structuralist nor post-structuralist (at least according to the most common definitions of these terms), nor is it phenomenological, but rather seeks to transcend these approaches (see Dreyfus \& Rabinow, 1983). To sum up, in fundamentalist discourse, instructionist classroom management is an ideological tool by which the education system extends its hegemony over students. The instructionist classroom management theory advocates that all subjects must reflect bureaucratic beliefs and values. This is implied in objectives, curricula content, pedagogy, and other aspects-because all textbooks are perceived as being imbued with the ethical values of Fordism, Taylorism, behaviourism and bureaucracy. 


\section{Philosophical Perspectives on Instructionist Classroom Management}

To start with, instructionist classroom management, among others, draws on the positivist paradigm, Fordism, Taylorism, behaviourism and bureaucracy. Instructionist classroom management conceptualises power as domination. For Foucault, power is "ubiquitous" and beyond agency or structure. On the other hand, Bourdieu sees power as culturally and symbolically created, and constantly relegitimised through an interplay of agency and structure. The main way this happens is through what Bourdieu calls "habitus" or socialised norms or tendencies that guide behaviour and thinking. "Habitus" is "the way society becomes deposited in persons in the form of lasting dispositions, or trained capacities and structured propensities to think, feel and act in determinant ways, which then guide them" (Wacquant, 2005: p. 316). With this in mind, instructionist classroom management qualifies as "habitus" and can be perceived as a set of socialised norms. It plays a central role in societal power relations, as this provides the means for a noneconomic form of domination and hierarchy.

The ideas of Foucault, Lacan, Anglo-Saxon cultural studies and the debate about Fordism, Taylorism, scientific management, and bureaucracy, underpin instructionist classroom management theory and practice. At philosophical level, instructionist classroom management is informed and guided by a traditional or classical viewpoint of management principles, behaviourist and objectivist tradition. It thus flows from theoretical frameworks of mechanistic worldview (bureaucracy, Taylorism, Fordism, behaviourism, objectivity, etc.). In practice, the activities are largely dominated and characterised by a topdown approach. In this article, instructionist classroom management is explored from an organisational perspective, where modernist organisational theory will be employed. The following key aspects of bureaucratisation (power and control), Taylorism (productivity and outputs), and Fordism (production) will form the pillars of the discourse. Each of these aspects is underpinned by a deeper philosophical understanding of what it means to manage (exerting power and control, achieving results through well organised processes, etc.).

\section{Bureaucratisation (Power and Control)}

Outstandingly, bureaucracy is an instrument of power, a social system to effect it (power), and a tool of political hegemony. The concept "bureaucracy" is most closely associated with Max Weber, a German social historian. It was intended to standardise far more than the conduct of public business (Bottery, 1992: p. 35). Bureaucratic organisations or systems are characterised by rules, impersonality, division of labour, hierarchical structure, authority structure, lifelong commitment and rationality. Bottery (1992: p. 35) asserts that the functions of bureaucracy are two-fold: to impose upon the society the kind of order which perpetuates its domination; and to conceal this domination by means of unending flow of form-filling, task division and constant supervision.

Control is an essential element in any organisation management. For an organisation like a school to function effectively and efficiently in monitoring the achievements and objectives, a form of control should be adopted. At the heart of bureaucracy are four primary mechanisms of social influence and control, namely authority, power, persuasion and exchange. These me- chanisms of social influence and control represent the fundamental tools for teacher professional development. Power is reflected in "the probability that one actor within a social relationship will be in position to carry out his own will despite resistance" (Spady \& Mitchell, 1979: p. 99). Du Preez (1994: p. 295) defines "power" as the ability a person has to influence others. In addition, the element of "influence" causes behavioural change that results directly or indirectly from the actions and/or examples of individuals or groups. Thus, power and influence are fundamental to change the behaviour or attitudes of an individual or a group. Power-based control is initiated directly through interpersonal demand and institutional mandate, or indirectly through specific manipulations of resources (Spady \& Mitchell, 1979: p. 99).

Persuasion operates on the basis of acknowledged legitimacy, and it involves presenting the subordinates with reasons for accepting control from the subordinate (Spady \& Mitchell, 1979: p. 102). The primary preconditions for successful persuasion are for the persuaders to have at least one established base of legitimacy and for the subordinates to trust them. Exchange is a control process closely related to power. According to Spady and Mitchell (1979: p. 99), exchange occurs when resources are more evenly distributed among the competing parties so that no one actor is able to establish a clear dominance. Thus, power and exchange exist on a continuum, with total domination possible only if the subordinate party has both a true monopoly of critical resources and the necessary capacity to enforce their distribution (Spady \& Mitchell, 1979: p. 100).

Authority is only a subset of power relationships in which the use of power is limited through social endorsement or justification (Spady \& Mitchell, 1979: p. 101). For Hellriegel and Slocum (1991: p. 320), authority is basically the right to decide and act. It is rooted in personal orientations and experiences that tie the superordinate who is "in authority" to a subordinate who is "under authority" (Spady \& Mitchell, 1979: p. 101). Furthermore, people respond to influence as authoritative when they perceive in an encounter the opportunity to realise their own significance, not merely satisfy the intentions of someone else because of the attractiveness or threat of external resources. Thus, authoritative control is characterised by supportive and collaborative rather than competitive interactions (Spady \& Mitchell, 1979: p. 102).

Given that authority is universal, the authority of the policymaker or bureaucrat in the education system is unique and is based on the rules that apply to the education system as a social relationship. Also, the authority of the policymaker or bureaucrat is based on his/her professional status as the holder of authority. The policymaker or bureaucrat, as supervisor, is part of the official authority structure of the education system and is given discretionary power by the department to give programs on professional development. It must therefore be kept in mind that authority is not solely "power or right to enforce obedience or give orders and make orders".

\section{Taylorism and Fordism (Production, Productivity and Outputs)}

Frederick Taylor (1856-1915) is viewed as the "Father of Scientific Management" and was nicknamed "Speedy" Taylor for his reputation as an efficiency expert in America from 1900-1930, but his influence stretched beyond that. Among 
others, scientific management's philosophy is that management practices should be based on proven fact and observation, not on hearsay or guesswork, and focuses on individual workermachine relationships in manufacturing plants. His writing emphasised standardisation, time and task study, systematic selection and training and pay incentives.

In motivating the employees to work to their fullest capacity, Taylor maintained that higher productivity would be maintained if productivity and remuneration were combined (Hellriegel \& Slocum, 1991: p. 48; Van der Westhuizen, 1995: p. 67). He also believed that increased productivity ultimately depended on finding ways to make workers more efficient (Bottery, 1993: p. 24), and he was convinced that efficiency could be increased by having workers perform routine tasks that did not require them to make decisions (Hellriegel \& Slocum, 1991: p. 48). Taylorism and Fordism are characterised by emphasis on productivity, output and profits; pyramid and structure (Ford — production line); control and efficiency (Taylor); and effectiveness and efficiency. Productivity, according to Van Niekerk (1994: p. 216), is the relationship between output and input, where output is usually measured in physical units whilst input is measured with regard to labor in terms of man-hours and with regard to capital in monetary or physical unit. The Taylorist ideology and approach were not confined to industries. They were also applicable to various fields of study, inter alia to politics, psychology, science, and more specifically, teaching and education. For example, education management theorists have traditionally borrowed ideas from industrial settings.

In light of the above, instructionist classroom management practices do not happen in a vacuum - they constitute a kind of order which perpetuates Fordist, Taylorist and bureaucracic domination. These practices are undergirded by particular theories and particular conceptions of humankind. Among others, instructionist classroom management is rooted in positivist, objectivistic/modernistic and/or behaviourist and Christian-orientated (Calvinist) philosophy. Within this context, instructionist classroom management then becomes one station in a production line that needs to fit into a larger machine like-organisation. From an organisational perspective, it could be inferred that instructionist classroom management is hierarchical with all the power centralised in the teacher as the carrier of the knowledge that needs to be transferred to learners, and it is organised around the results to be achieved-curriculum and evaluation dominated. Instructionist classroom management is bounded-certain tasks to be completed in specific time-frames - and it is teacher-centred as the initiator, organiser and manager of the learning that must take place, and learners are recipients of knowledge to be absorbed and regurgitated in exams. Hence, in Fordist (scientific management) discourse, classroom management is an ideological tool by which education system extends its hegemony over students. The instructionist classroom management theory advocates that all subjects must reflect scientific and/or behaviourist beliefs and values. This is implied in the objectives, curricula content, pedagogy, and other aspects. In the scientific paradigm, textbooks are perceived as being imbued with the ethical values of behaviourism.

\section{Teacher's Power as a Tool for Social Reproduction and Domination in an Instructionist Classroom Setting}

There is a strong connection between power and social re- production. Power as a tool of social reproduction shapes individuals (students) to be able to play a part in power's operations. Schools are institutions for social reproduction and the classrooms are key sites for the reproduction of social identities and unequal relations of power. On the one hand, classrooms serve the purpose of social phenomena of reproduction and transformation. On the other hand, classrooms become sites for students' struggles and oppositional practices that however, often lead students to participate in their own domination. This article assumes that the theoretical notions of cultural capital, symbolic violence, and social capital articulated by Bourdieu (1973, 1977, 1991, 1986), and Bourdieu and Passeron (1977) can serve as analytical tools for achieving a greater understanding of social phenomena of reproduction and transformation.

The concept of cultural capital (Bourdieu, 1973, 1977, 1991; Bourdieu \& Passeron, 1977) refers to language use, skills, and orientations, dispositions, attitudes, and schemes of perception (also collectively called habitus) that children are endowed with by virtue of socialisation in their families and communities. Bourdieu defines "habitus" as a system of lasting, transposable dispositions which, integrating past experiences, functions at every moment as a matrix of perceptions, appreciations, and actions and makes possible the achievement of infinitely diversified tasks, thanks to analogical transfers of schemes permitting the solution of similarly shaped problems.

Conspicuously, cultural capital exists in three forms: 1) as incorporated in the "habitus", and is to a large extent created through primary pedagogy, that is, in (early) childhood; 2) cultural capital is objectivised in cultural articles; and 3) it exists institutionalised in cultural institutions and is expressed in terms of certificates, diplomas and examinations (Bourdieu, 1977, 1979; Bourdieu \& Passeron, 1977). Bourdieu argues that through familial socialisation, children of the socioeconomic elite receive both more of and the right kind of cultural capital for school success (i.e., their "habitus" becomes their cultural capital). Hence, the notion of cultural capital describes the disadvantaged position of ethnic and linguistic minorities and to problematise the notion that state-run education in modern societies is built on meritocracy and equal opportunity.

Bourdieu's (1984) idea of symbolic violence concerns how the disadvantaging effect of the schooling system is masked or legitimised in people's consciousness. School failure can be conveniently attributed to individual cognitive deficit or lack of effort and not to the unequal initial shares of the cultural capital both valued and legitimised at school:

The dominated classes allow [the struggle] to be imposed on them when they accept the stakes offered by the dominant classes. It is an integrative struggle and, by virtue of the initial handicaps, a reproductive struggle, since those who enter this chase, in which they are beaten before they start... implicitly recognize the legitimacy of the goals pursued by those whom they pursue, by the mere fact of taking part (Bourdieu, 1984: p. 165).

Symbolic violence, according to Bourdieu, is the imposition of representations of the world and social meanings upon groups in such a way that these representations are experienced as legitimate. This is achieved through a process of misrecognition. This article acknowledges the critics of the concept "social capital”. However, Bourdieu's concept of social capital puts the emphasis on conflicts and the power function (social relations that increase the ability of an actor to advance her/his interests). 
Social capital has become a popular concept in development policy partly because it seemingly specifies a resource to be tapped, a productive asset that can be strategically mobilised by individuals and groups for particular ends (Cleaver, 2005: p. 893).

Against this background, teachers may be regarded as agents of bureaucratic hegemony, for good or for ill, in any society. Bourdieu's theory about the role of schools and teachers in the transmission of intergenerational inequalities rests on a number of assumptions about the teacher population and the school context. The role of the school is to promote arbitrary cultural values (classroom discipline, classroom order) via teachers; and on the grades teachers give in assessing student progress net of teachers' cultural capital and demographics (Tzanakis, 2011: p. 81). Teacher assessments of students, however, are argued to reflect not only students' aptitude and performance, but also their work habits, basic communicative and other non-cognitive skills. There is a fundamental relationship between notions of cultural capital, symbolic violence, and social capital and the state. The nature of this relationship demonstrates the role of power, politics, and ideology in accounting for historical trends in social capital formation and deterioration.

\section{Conclusion}

Discourse and power, as social interrelated constructs, can serve as analytical tools to achieve a greater understanding of instructionist classroom management. Instructionist classroom management practices constitute a kind of order which perpetuates Fordist, Taylorist and bureaucratic domination. These practices are undergirded by particular theories and particular conceptions of humankind. Within an instructionist classroom setting, the teacher's power as a tool of social reproduction shapes students to be able to play a part in power's operations. Hence, teachers can be regarded as agents of bureaucratic hegemony, for good or for ill, in any society.

\section{REFERENCES}

Ball, S. J., \& Goodson, I. (2007). Education, globalisation and new times. New York: Routledge.

Bottery, M. (1993). The ethics of educational management. London: Cassel.

Bourdieu, P. (1973). Cultural reproduction and social reproduction in knowledge, education and cultural change. London: Tavistock.

Bourdieu, P. (1977). Outline of a theory of practice. Cambridge: Cambridge University Press.

Bourdieu, P., \& Passeron, J. C. (1977). Reproduction in education, society and culture. London: Sage.

Bourdieu, P. (1984). Distinction: A social critique of the judgement of taste. London: Routledge \& Kegan Paul.

Bourdieu, P. (1986). The forms of capital. In J. G. Richardson (Ed.),
Handbook of theory and research for the sociology of capital (pp. 241-258). New York: Greenwood.

Bourdieu, P. (1991). Language and symbolic power. Cambridge, MA: Harvard University Press.

Cleaver, F. (2005). The inequality of social capital and the reproduction of chronic poverty. World Development, 33, 893-906. doi:10.1016/j.worlddev.2004.09.015

Corson, D. (1995). Discourse and power in educational organizations. Cresskill, NJ: Hampton.

Deacon, R. (2006). Michel Foucault on education: A preliminary theoretical overview. South African Journal of Education, 26, 177-187.

Dreyfus, H. L., \& Rabinow, P. (1983). Michel foucault: Beyond structuralism andhermeneutics (2nd ed.). Chicago: University of Chicago Press.

Du Preez, N. P. (1994). Delegation, authority and power. Pretoria: HAUM.

Foucault, M. (1972). The archaeology of knowledge and the discourse on language. New York: Pantheon.

Foucault, M. (1977). Discipline and punish. New York: Pantheon.

Foucault, M. (1978). The history of sexuality: An introduction. Hammonsworth: Penguin.

Foucault, M. (1998). The history of sexuality: The will to knowledge. London: Penguin.

Harrington, A. (2006). Social theory and theology. In G. Delanty (Ed.), Handbook of contemporary European social theory (pp. 37-49). New York: Routledge.

Harrison, P. R. (1992). Michel Foucault. In P. Beilharz, \& St Leonards (Eds.), Social theory: A guide to central thinkers (pp. 84-89). NSW: Allen \& Unwin.

Hellriegel, D., \& Slocum, J. W. (1991). Management. New York: Addison-Wesley.

Hutcheon, L. (1991). Discourse, power, ideology: Humanism and postmodernism. New York: Routledge.

Kehily, M. (2001). Bodies in school: Young men, embodiment, and heterosexual masculinities. Men and Masculinities, 4, 173-185. doi:10.1177/1097184X01004002005

Popkewitz, T. S. (1997). Restructuring of social and political theory in education: Foucault and a social epistemology of school practices. Educational theory, 47, 287-313. doi:10.1111/j.1741-5446.1997.00287.x

Spady, W. G., \& Mitchell, D. E. (1979). Authority and the management of classroom activities. In D. L. Duke (Ed.), Classroom management (pp. 75-115). Chicago: University of Chicago Press.

Talbani, A. (1996). Pedagogy, power and discourse: Transformation of Islamic education. Comparative Education Review, 40, 66-82. doi:10.1086/447356

Tzanakis, M. (2011). Bourdieu's social reproduction thesis and the role of cultural capital in educational attainment: A critical review of key empirical studies. Educate, 11, 76-90.

Van der Westhuizen, P. C. (1995). The development of scientific management thought and some developments in the field of educational management. In P. C. van der Westhuizen (Ed.), Effective educational management (pp. 63-161). Pretoria: Kagiso.

Van Niekerk, J. T. (1994). Coordination and productivity. In J. Kroon (Ed.), General management (pp. 197-218). Pretoria: HAUM.

Weedon, C. (1997). Feminist practice and poststructuralist theory (2nd ed.). Oxford: Blackwell. 